\title{
Programy niemieckich partii politycznych w wyborach do Parlamentu Europejskiego w 2014 roku. Wybrane aspekty
}

\section{Wprowadzenie}

Parlament Europejski przeszedł w ciagu ponad sześciu dekad swego istnienia znaczącą ewolucję, zarówno w wymiarze ilościowym, jak i jakościowym. Przejawiała się ona z jednej strony niemal dziesięciokrotnym powiększeniem składu izby (poczynając od Zgromadzenia Europejskiej Wspólnoty Węgla i Stali), z drugiej zaś stopniowym poszerzaniem jej kompetencji - od organu doradczo-kontrolnego do instytucji współtworzącej prawo Unii Europejskiej (szerzej zob. Kosman, 2009, s. 235-257). Jego znaczenie zatem systematycznie rosło, co stanowi istotny argument na rzecz badawczego zainteresowania tym niezwykłym eksperymentem w dziejach współczesnych organizacji międzynarodowych - wszak jest to jedyny w skali świata tego rodzaju organ wyłaniany w drodze powszechnych wyborów. Jednak zjawiska kryzysu gospodarczego targającego Starym Kontynentem w ostatnich latach oraz rodzącego się w krajach Unii poczucia rozczarowania i niepewności co do kierunku procesów integracyjnych (Mudde, 2014, s. 16-24) spowodowały, że przed wyborami 2014 r. przewidywano wzrost poparcia dla ugrupowań eurosceptycznych (Kietz, von Ondarza, 2014, s. 37-41). W samych Niemczech natomiast kampanii wyborczej towarzyszyło umiarkowane zainteresowanie, tym bardziej, że główni rywale - chadecy i socjaldemokraci - z końcem 2013 r. zbudowali wspólną koalicję rządową - fakt ten zatem sprzyjał raczej łagodnej niż konfrontacyjnej strategii wyborczej (choć te drugie akcenty także się pojawiły).

Celem niniejszego artykułu jest prezentacja najważniejszych treści programowych czternastu niemieckich partii politycznych (na dwadzieścia pięć biorących udział w wyborach), które wyborcy obdarzyli zaufaniem i powierzyli im mandaty przedstawicielskie w Parlamencie Europejskim. Dla przejrzystości wywodu, każdej z nich poświęcony jest co najmniej odrębny akapit. Część programów prezentuje się bardzo okazale, licząc sobie po kilkadziesiąt stron i szerokie spektrum treści, obejmując wszystkie najważniejsze aspekty funkcjonowania UE. W innych przypadkach są to mniejsze dokumenty (od kilku do kilkunastu stron) - dotyczy to zwykle mniejszych partii, zwykle koncentrujących się na jakiejś konkretnej dziedzinie aktywności publicznej w sferze międzynarodowej i powierzchownie traktujących inne obszary (lub w ogóle je pomijając). Odrębnym przypadkiem jest jednostronicowy quasi-program formacji PARTEI. W toku analizy programów wyborczych autor skupił się a priori na zagadnieniach Wspólnej Polityki Zagranicznej i Bezpieczeństwa oraz problemach in- 
stytucjonalnych w UE. Wynika to z jednej strony z rosnącego $w$ ostatnim czasie znaczenia problematyki bezpieczeństwa międzynarodowego, z drugiej zaś z refleksji związanej z przyszłością procesów integracyjnych w Europie, której istotnym elementem są reformy instytucjonalne. Poza omówieniem tych dziedzin, postanowiono zaakcentować te zagadnienia, które odgrywały pierwszoplanową rolę w programach poszczególnych partii i w jakimś stopniu decydowały o ich obliczu (dotyczy to zwłaszcza mniejszych partii, które znajdowały sobie zwykle własną „niszę” programową).

W ostatnich latach w Niemczech kilkukrotnie modyfikowano ustawę o wyborach do Parlamentu Europejskiego (Gesetz über die Wahl..., 1994, s. 424-432). Od 1989 r. funkcjonowała zasada podziału mandatów Hare-Niemeyera, zaś od 2009 r. Sainte-Laguë. W wyborach z 2009 r. obowiązywała jeszcze klauzula pięcioprocentowa, która stanowiła skuteczną barierę dla mniejszych partii. Jednak dnia 9 grudnia 2011 r. Federalny Trybunał Konstytucyjny uznał ją za niezgodną z Ustawą Zasadniczą (Leitsätze..., 2011). Dwa lata później, 10 października 2013 r., weszła w życie ustawa wprowadzająca klauzulę trzyprocentową (Fünftes Gesetz..., 2013, s. 3749-3751). Została ona zaskarżona przez kilkanaście mniejszych partii, domagających się większych szans w rywalizacji wyborczej. Ich racje ponownie rozpatrzył Federalny Trybunał Konstytucyjny, i tym razem uznając ją za niezgodną z Ustawą Zasadniczą w orzeczeniu z 26 lutego 2014 r. (Leitsätze..., 2014). Była to znakomita wiadomość dla mniejszych ugrupowań, przed którymi otworzyły się całkiem realne perspektywy wprowadzenia swych przedstawicieli do Parlamentu Europejskiego. Jak się miało okazać, aż siedem ugrupowań skorzystało na tej modyfikacji, uzyskując po jednym mandacie. Łącznie aż czternaście partii niemieckich znalazło się w Parlamencie Europejskim (w przypadku zachowania klauzuli trzyprocentowej byłoby ich zaledwie siedem).

\section{Programy wyborcze}

Triumfatorem niemieckich wyborów do PE stała się Unia Chrześcijańsko-Demokratyczna (Christlich-Demokratische Union - CDU), która startowała pod hasłem „Razem skuteczni w Europie" (Gemeinsam erfolgreich in Europa). Program wyborczy pod takim właśnie tytułem uchwalony został 5 kwietnia 2014 r. CDU jednoznacznie opowiedziała się w nim za umacnianiem więzi integracyjnych i trwałej obecności Niemiec w Unii Europejskiej. W preambule wyeksponowano wątki sięgające do ideowych źródeł partii, których egzemplifikację stanowiło odwołanie do chrześcijańsko-zachodnich korzeni Europy. Nawiązano również do kryzysu gospodarczego na kontynencie i konieczności intensyfikacji działań w celu jego zwalczania. Godny podkreślenia jest fakt, że już w pierwszym rozdziale (Przyszłość Niemiec w Europie) odwołano się do partnerstwa z najbliższymi sąsiadami - Francją i Polską (Gemeinsam erfolgreich..., 2014, s. 4).

Problem miejsca Europy w świecie i jej zaangażowania w polityce międzynarodowej został poruszony w ostatnim rozdziale, noszącym tytuł Odpowiedzialność Europy $w$ świecie (Europas Verantwortung in der Welt). Chadecy opowiedzieli się za dalszym instytucjonalnym wzmacnianiem zewnętrznych zdolności do działania UE, co można wywnioskować z zapisów dotyczących wzmocnienia pozycji Wysokiego Przedstawiciela ds. Zagranicznych i Polityki Bezpieczeństwa, jak również jego aparatu admini- 
stracyjnego, tj. Europejskiej Służby Działań Zewnętrznych. Śmiałym postulatem ze strony CDU jest również chęć przekształcenia mechanizmu Wspólnej Polityki Bezpieczeństwa i Obrony w kolektywną obronę Unii Europejskiej. Przypomnijmy, że taka możliwość została otwarta na mocy zapisów Traktatu o Unii Europejskiej w następstwie zawarcia i wejścia w życie Traktatu z Lizbony (art. 42 ust. 2 TUE) (szerzej zob. Węc, 2011, s. 258-267). Wiąże się to z wymogiem poprawy zdolności militarnych poszczególnych państw UE. Na dłuższą metę - według programu CDU - należałoby stworzyć armię europejską, co nosiło znamiona idei bardzo odważnej, rodzącej skojarzenia z nieudanym projektem Europejskiej Wspólnoty Obronnej z pierwszej połowy lat pięćdziesiątych XX wieku. W ramach postulowanego podziału zadań w dziedzinie bezpieczeństwa i obrony ponownie podkreślono gotowość Niemiec do bliższej kooperacji z najbliższymi sąsiadami - Polską i Francją. Wśród chadeckich postulatów znalazło się również wspólne planowanie obronne, jak i projekty w sektorze zbrojeniowym. W tradycyjnej orbicie zainteresowania niemieckich chadeków od początków istnienia RFN znajdowała się współpraca transatlantycka, nic więc dziwnego, że program CDU położył istotny nacisk także na tę sferę, akcentując pozytywne oczekiwania wynikające z bliskiej współpracy pomiędzy NATO i UE.

W programie CDU znalazły swoje odzwierciedlenie bieżące wydarzenia w Europie. Pokaźny fragment dotyczy Rosji i jej interwencji na Ukrainie w pierwszej połowie 2014 r. Wyrażono dążenie do budowy dobrosąsiedzkich stosunków z Rosją, uzależniając ten proces jednak od gotowości Moskwy do dotrzymywania swych zobowiązań międzynarodowych i przestrzegania standardów demokracji i praworządności. Wyrażono sprzeciw wobec rosyjskiej polityki nacisku na państwa sąsiednie, wspierania w nich ruchów separatystycznych, domagając się wycofania sił rosyjskich z Ukrainy (z wyjątkiem floty czarnomorskiej, przebywającej w oparciu o porozumienie rosyjsko-ukraińskie). Potępiono politykę przemocy byłego prezydenta Wiktora Janukowycza, która - zdaniem autorów dokumentu - odebrała mu wszelką legitymację do sprawowania rządów. Opowiedziano się za wdrożeniem postanowień układu o stowarzyszeniu UE z Ukrainą, który to kraj na dłuższą metę mógłby pełnić rolę łącznika pomiędzy Unią a Rosją. Nie było natomiast mowy o perspektywie członkostwa Ukrainy w UE, co potwierdza dość chłodny stosunek niemieckiej klasy politycznej dla takiej perspektywy.

W programie wyborczym chrześcijańskich demokratów znalazły się także zapisy dotyczące współpracy z krajami rozwijającymi się, umacniania współpracy w ramach ONZ (włącznie z niemieckim postulatem uzyskania stałego miejsca w Radzie Bezpieczeństwa), umacniania praw człowieka (w tym postulat znoszenia kary śmierci w państwach ją utrzymujących, poprawy losu chrześcijan prześladowanych w różnych zakątkach świata). W odniesieniu do polityki rozszerzenia UE chadecki program okazał się dość powściagliwy. Dynamiczne tempo powiększania się UE w ostatnich dekadach uznano za zjawisko uzasadnione, lecz jego kontynuacja stanowiłaby nadmierne obciążenie dla UE i odbywałaby się kosztem jej efektywności. Unia zatem powinna zostać otwarta na nowych kandydatów, lecz proces przyjmowania kolejnych państw powinien zostać spowolniony oraz ujęty w rygorystyczne kryteria polityczne i gospodarcze. Chadecy ponownie przytoczyli swój powtarzany od lat postulat budowy strategicznego partnerstwa z Turcją bez przyjmowania jej do UE (Gemeinsam erfolgreich..., 2014, s. 75-80). 
Program Unii Chrześcijańsko-Społecznej (CSU), uchwalony na zjeździe partii 10 maja 2014 r., w głównych punktach był zbieżny z europejskimi założeniami jej federalnej siostry. Zasadniczą różnicą - siłą rzeczy - było postawienie Bawarii w centrum uwagi dokumentu, o czym świadczyły hasła typu „Bawaria jest krajem w sercu Europy” czy „silna Bawaria jest dobra dla Europy”. Ten osiemnastostronicowy dokument składa się w zasadzie ze zwięzłych, przejrzystych haseł, po czym następuje ich krótkie rozwinięcie. Dokument CSU także w sposób bardziej jednoznaczny niż CDU wyraża opinię, że Unia Europejska obecnie dotarła do kresu swych możliwości w zakresie przyjmowania i absorpcji nowych państw, dlatego proces rozszerzenia musi zostać zatrzymany. Dobitnie przeciwstawia się członkostwu Turcji w Unii. Państwo to zostało uhonorowane jako istotny partner Unii i ,dobry przyjaciel w NATO”, jednak pełne członkostwo byłoby obciążeniem zarówno dla Unii, jak i samej Turcji. Podobnie jak CDU, jej bawarska siostra opowiada się z uprzywilejowanym partnerstwem Unii z Turcją. Uczciwe postępowanie z Turcją wymaga jasnego stanowiska i przerwania bieżących negocjacji akcesyjnych. Z kolei w sprawie kryzysu na Ukrainie głos CSU w omawianym dokumencie programowym jest ostrożniejszy niż w przypadku CDU. Bawarczycy nie wychodzą poza bezpieczne formuły o poparciu dla politycznego i gospodarczego wzmocnienia Ukrainy jako istotnego partnera UE, opowiadając się za pełnieniem przez nią funkcji pomostu pomiędzy UE a Rosją i nawołując rząd niemiecki do „roztropnego postępowania” (besonnene Vorgehensweise) w konflikcie ukraińsko-rosyjskim. Także w zakresie Wspólnej Polityki Zagranicznej i Bezpieczeństwa CSU nie wychodzi poza ogólniki o potrzebie większej efektywności w tej dziedzinie, lepszego wykorzystania zdolności wojskowych i współpracy w ramach NATO (Europaplan Bayern..., 2014, s. 4-5). Charakterystyczna jest natomiast duża wyrazistość programu w innych, wewnątrzunijnych kwestiach, jak np. powstrzymanie migracji do Unii, ograniczenie prawa azylowego, wzmocnienie szczebla państwowego (zwłaszcza parlamentów narodowych) i regionalnego w Unii, wprowadzenia w Niemczech prawa do referendum w najistotniejszych kwestiach europejskich (przyjmowanie nowych państw do UE, cedowanie na Unię istotniejszych kompetencji przez państwa członkowskie czy obciążenia finansowe Niemiec na rzecz UE), ograniczenie liczebności i kompetencji Komisji Europejskiej, redukcja budżetu UE, wzmocnienie obecności języka niemieckiego $\mathrm{w}$ instytucjach unijnych, ochrona miejsc pracy w Niemczech, ograniczenie lub blokowanie pomocy dla państw popadających w kryzys i odmawiających gruntownych reform (Europaplan Bayern..., 2014, s. 6-15). Lektura programu odsłania oblicze CSU jako partii ostrożnej w sprawach europejskich, nastawionej na ochronę interesów narodowych Niemiec. Cechy te mogą posłużyć za ilustrację różnic $\mathrm{w}$ zestawieniu $\mathrm{z}$ - mimo wszystko - bardziej proeuropejskim programem CDU.

Program Socjaldemokratycznej Partii Niemiec (SPD) przygotowany w związku z wyborami do Parlamentu Europejskiego, ogłoszony został 25 maja 2014 r. W porównaniu z programem CDU jest dokumentem skromniejszym pod względem objętości (liczy sobie zaledwie 14 stron, przy 84-stronicowym programie CDU), tym samym treści dotyczące roli UE na arenie międzynarodowej są również mniej rozbudowane. W wielu kwestiach program SPD pokrywa się z dokumentem CDU. Socjaldemokraci opowiadają się za wzmocnieniem Wspólnej Polityki Zagranicznej i Bezpieczeństwa, przy czym silny akcent kładą na dyplomatyczne i cywilne środki w zakresie rozwiązywania 
problemów bezpieczeństwa. Podobnie jak chadecy, SPD w dalszej perspektywie opowiada się za utworzeniem armii europejskiej, poddając ten proces pod kontrolę Parlamentu Europejskiego. Stosunek do rozszerzenia UE jest natomiast znacznie odważniejszy aniżeli w przypadku CDU. Socjaldemokraci opowiadają się za otwarciem bram UE dla nowych kandydatów, oczywiście pod warunkiem spełniania kryteriów członkostwa. Brak zatem charakterystycznych dla chadeków wątpliwości związanych z tempem rozszerzenia i potencjalnymi zagrożeniami dla efektywności i spoistości UE. Innym elementem odróżniającym socjaldemokratów od chadeków jest pozytywny stosunek do ewentualnego członkostwa Turcji w UE. W programie zaznaczono, że proces negocjacji akcesyjnych z Turcją ma na celu jej przystąpienie do Unii. Jednocześnie nawoływano rząd w Ankarze do przestrzegania zasad demokracji, państwa prawa i praw człowieka. Bardziej powściagliwy niż w przypadku CDU był też w swej formie przekaz dotyczący Ukrainy i Rosji w kontekście toczącego się konfliktu między obydwoma państwami. Problematyka ta została wpleciona w kwestie Europejskiej Polityki Sąsiedztwa. Socjaldemokraci ograniczyli się do ostrożnych formuł dotyczących współpracy i partnerstwa z Ukrainą w oparciu o układ stowarzyszeniowy. Opowiedziano się za kształtowaniem przyszłości kraju w oparciu o odrzucenie konfrontacji i dialog na bazie szerokiego konsensu społecznego. W odniesieniu do Rosji socjaldemokraci również nie wykroczyli poza tradycyjne zapisy o partnerstwie FR z Europą, wspólnym rozwiązywaniu problemów międzynarodowych i dialogu dotyczącego ,krytycznych tematów" związanych z demokracją i prawami człowieka (Europa eine neue Richtung..., 2014, s. 10-13). Nie pojawia się żadna wzmianka na temat konfliktu rosyjsko-ukraińskiego rozwijającego się w pierwszej połowie 2014 r. Można to uznać za kolejne potwierdzenie większej niż w przypadku chadeków wrażliwości na rosyjski punkt widzenia, cechujący socjaldemokratów. Program zawiera natomiast pewne wątki związane z tkanką instytucjonalną UE. Opowiada się za wzmocnieniem Parlamentu Europejskiego, m.in. poprzez nadanie mu pełnej inicjatywy prawodawczej (w miejsce istniejącej obecnie inicjatywy pośredniej, tj. poprzez zaangażowanie Komisji Europejskiej, zgodnie z art. 225 Traktatu o funkcjonowaniu Unii Europejskiej), oraz Komisji Europejskiej, która powinna ewoluować w kierunku rządu europejskiego (Europa eine neue Richtung..., 2014, s. 5-6).

W programie Wolnej Partii Demokratycznej (FDP), liczącym sobie 28 stron, priorytetem są kwestie gospodarcze, co nie zaskakuje biorąc pod uwagę, że jest to tradycyjna domena tej partii. Dominują także inne, typowe dla liberałów postulaty - na rzecz wzrostu gospodarczego, społecznej gospodarki rynkowej, surowego przestrzegania porozumień z zakresu dyscypliny finansowej, wzmacniania przedsiębiorstw, rozwijania oświaty, ochrony środowiska, praw konsumentów, praw obywatelskich, wzmacniania demokracji, zasady subsydiarności czy poczucia odpowiedzialności za własny los. FDP wysuwa odważny postulat doprowadzenia UE do unii politycznej opartej na zasadach federalizmu, której ostatecznym celem powinno być państwo związkowe (Bundesstaat). Pojawia się także kontrowersyjny z polskiej perspektywy postulat wzmocnienia zasady wielu prędkości w UE, ponadto wzmocnienia metody konwentu jako drogi do reform traktatowych, wprowadzenia w Niemczech instytucji referendum na szczeblu federalnym w sprawach europejskich czy zwiększenia prerogatyw Parlamentu Europejskiego. W ramach tego ostatniego punktu liberałowie postulują m.in. 
wprowadzenie pełnego prawa inicjatywy prawodawczej, jak również jednolitego prawa wyborczego, w ramach którego głos każdego obywatela miałby równą wagę (Programm der Freien..., 2014, s. 6-7). Ten ostatni postulat wydaje się na dzień dzisiejszy nieco kontrowersyjny z punktu widzenia mniejszych, słabszych demograficznie państw, dla których obecnie funkcjonująca reguła degresywnej proporcjonalności jest sprawiedliwym wypośrodkowaniem pomiędzy zasadą suwerennej równości państw a dowartościowaniem siły demograficznej. Towarzyszy temu zamiar zredukowania liczebnego i wzmocnienia Komisji Europejskiej, zapewnienia zasady otwartości obrad Rady UE, czy wręcz rewolucyjny postulat likwidacji Rady Europejskiej. Liberałowie są ponadto przeciwni mechanizmom naruszającym prawo obywateli do prywatności, w tym nadmiernemu zbieraniu danych osobowych. Z tej przyczyny domagają się powiązania rozmów o transatlancyckiej strefie wolnego handlu właśnie z porozumieniem dotyczącym ochrony danych osobowych (Programm der Freien..., 2014, s. 7-11). W części programu poświęconej Wspólnej Polityce Zagranicznej i Bezpieczeństwa liberałowie wyrażają wątpliwości co do efektywności procesów decyzyjnych w tej-międzyrządowej-sferze współdziałania. Akcentują, że poziom integracji w tym zakresie nie nadąża np. za wspólną polityką handlową czy integracją walutową w strefie euro. Unia jest podzielona w sferze polityki zagranicznej, co jest czynnikiem osłabiającym jej efektywność na zewnątrz (Programm der Freien..., 2014, s. 24). Opinię taką można odczytać jako krytykę zasady jednomyślności w ramach WPZB i być może nieco zawoalowany postulat jej zmiany w kierunku uwspólnotowienia. Rozwijaniu WPZB służyłoby także instytucjonalne wzmocnienie Europejskiej Służby Działań Zewnętrznych. Nie zaskakuje także dążenie do wzmocnienia Wspólnej Polityki Bezpieczeństwa i Obrony oraz dalszego opierania bezpieczeństwa europejskiego o NATO. Pojawia się hasło o konieczności poprawy europejskich zdolności obronnych, jednak - jak wynika z jego rozwinięcia - w zasadzie ogranicza się do propozycji obniżenia środków na obronność i lepszego gospodarowania nimi. FDP opowiada się ponadto za kontynuacją procesu rozszerzenia UE pod warunkiem twardego spełniania kryteriów politycznych i gospodarczych członkostwa przez kandydatów. Dotyczy to także Turcji. Liberałowie opowiadają się również za wyważoną polityką imigracyjną i azylową, uwzględniającą potrzeby rozwoju gospodarczego kontynentu w kontekście popytu na siłę roboczą (Programm der Freien..., 2014, s. 26-28).

Bardzo obszerny - liczący 145 stron - program wyborczy opublikował Sojusz'90/ Zieloni. Zgodnie z ich proweniencją, zasadnicze akcenty partia położyła na problemy ekologiczne, rozwojowe i obejmujące ochronę mniejszości. Obszerny rozdział został poświęcony pomysłom na wychodzenie państw UE z kryzysu gospodarczego trawiącego kontynent, zwłaszcza strefę euro. Jednym z haseł Zielonych stała się redukcja deficytu demokracji w Unii, m.in. poprzez wzmocnienie mechanizmów współdecydowania obywateli UE w sprawach europejskich. Do trudnych i kontrowersyjnych tematów zaliczyć można z pewnością przekształcenie Unii w koherentną przestrzeń chroniącą uchodźców spoza UE, poprzez stworzenie jednolitych i uczciwych reguł azylowych. W tym punkcie widać wyraźną sprzeczność w porównaniu z bawarskimi chadekami, demonstrującymi przekonanie o przeciążeniu Europy falami uchodźców. Do odważnych należy także postulat rozciągnięcia praw wyborczych obywateli UE na wszystkie rodzaje wyborów (a nie tylko, jak obecnie, wyborów lokalnych i do Parla- 
mentu Europejskiego). Zieloni domagają się większej przejrzystości zjawiska lobbingu w UE. Istotnym instytucjonalnym postulatem stało się okrojenie liczebne Komisji Europejskiej oraz zwiększenie praw Parlamentu Europejskiego, m.in. poprzez przyznanie mu pełnej inicjatywy prawodawczej. Zieloni zaproponowali również zwołanie europejskiego konwentu, który podjąłby debatę na temat przyszłej architektury Unii (Europa mitentscheiden..., 2014, s. 70-75). Problematyka stosunków zewnętrznych Unii została w programie także zdominowana hasłami sprawiedliwości na świecie, zwalczania ubóstwa, chorób, głodu, zanieczyszczeń, wzmacnianie prawa międzynarodowego, praw człowieka, globalną walkę z zanieczyszczeniem środowiska, etc. Unia jawi się tu jako potęga cywilna (Zivilmacht), której siła oddziaływania wyraża się raczej poprzez miękkie środki niż twardą siłę. Jednym ze sztandarowych postulatów jest samoopodatkowanie państw UE na pomoc rozwojową w wysokości $0,7 \%$ PKB, redukcja długów najuboższych państw czy zniesienie subwencji eksportowych w polityce rolnej UE. Zieloni opowiadają się za kontynuacją polityki rozszerzenia UE, co wyraźnie odróżnia ich od chadeków i zbliża do socjaldemokratów. Szczególnie dotyczy to państw bałkańskich oraz Turcji, która wprawdzie obecnie nie spełnia standardów demokratycznych, jednak powinna nadal prowadzić negocjacje akcesyjne. Zieloni eksploatują w dokumencie dawny argument na rzecz poprzednich rozszerzeń, zakładający że perspektywa przystapienia do UE będzie stanowiła dla kandydatów ważny impuls na rzecz przemian politycznych, gospodarczych i społecznych. Unia powinna ponadto działać na rzecz stabilności w najbliższym, tj. śródziemnomorskim i wschodnioeuropejskim sąsiedztwie. W określonej perspektywie powinien być zniesiony obowiązek wizowy dla Rosji i państw objętych Partnerstwem Wschodnim. W programie padły też słowa krytyki pod adresem Rosji z powodu odwrotu od demokracji w ostatnich latach. Pojawia się także postulat wzmocnienia ONZ. Zieloni, w odróżnieniu od chadeków, nie uważają za właściwe domaganie się dla Niemiec stałego miejsca w Radzie Bezpieczeństwa, opowiadając się raczej za reprezentacją całej Unii Europejskiej w tym organie. Co ciekawe, partia ekologów chciałaby w dalszej perspektywie znieść prawo weta w Radzie Bezpieczeństwa i wzmocnić pozycję Zgromadzenia Ogólnego. Zadaniem UE powinno być angażowanie się w działania na rzecz zwalczania kryzysów humanitarnych głównie miękkimi środkami, jednak nie wykluczając zaangażowania środków militarnych pod warunkiem każdorazowego mandatu Rady Bezpieczeństwa w takich sytuacjach. ONZ powinna być wyposażona we własne stałe oddziały, zamiast bazować na formacjach delegowanych każdorazowo przez poszczególne państwa. Do istotnych postulatów należy ograniczenie międzynarodowego handlu bronią i wzmocnienie kontroli Parlamentu Europejskiego nad tą dziedziną. PE powinien również mieć prawo do decydowania o każdorazowych operacjach wojskowych UE. Odważnie brzmi postulat reformy NATO, której celem winno być wkomponowanie sojuszu w międzynarodową architekturę bezpieczeństwa z udziałem UE i OBWE. Należy dążyć do zrównania pozycji państw europejskich ze Stanami Zjednoczonymi w ramach NATO. Rewolucyjnie brzmi postulat poddania Wspólnej Polityki Zagranicznej i Bezpieczeństwa UE większościowym procedurom decyzyjnym w Radzie UE (Europa mitentscheiden..., 2014, s. 95-119).

Kolejną partią, która wzięła udział w wyścigu wyborczym do Parlamentu Europejskiego, była Lewica. Jej program wyraźnie odróżniał się od innych prominentnych 
partii niemieckich wyraźną kontestacją dotychczasowego porządku europejskiego. W programie wyborczym Lewica za chlubę przypisuje sobie fakt, że jako jedyna z formacji politycznych w Bundestagu sprzeciwiała się europejskiemu paktowi fiskalnemu (Europa geht..., 2014, s. 13-14), pomyślanemu jako ważny instrument wspierający wyjście z kryzysu gospodarczego na kontynencie. Zamiast bolesnych kuracji redukowania wydatków w państwach dotkniętych kryzysem, Lewica proponuje „w skali europejskiej bardziej wciagnąć milionerów do finansowania społecznych i ekologicznych inwestycji lub projektów infrastrukturalnych" (Europa geht..., 2014, s. 14). Program obfituje w postulaty podważające fundamentalne zasady gospodarki rynkowej (np. upaństwowienie większych banków prywatnych, jednorazowe opodatkowanie posiadaczy majątków powyżej $1 \mathrm{mln}$ euro), stanowiąc w praktyce zbiór na pozór szczytnych, acz nierealnych haseł. Wiele miejsca w programie zajmują kwestie tolerancji i ochrony mniejszości, zwalczania rasizmu i faszyzmu, mocny nacisk położony jest na równouprawnienie płci (w tych kwestiach Lewica jest blisko Zielonych). Z kolei w zakresie zewnętrznej aktywności UE Lewica przedstawia cały szereg radykalnych postulatów, takich jak: zablokowanie rozmów na temat planowanej transatlantyckiej strefy wolnego handlu (Europa geht..., 2014, s. 27); odrzucenie wszelkiej przemocy w stosunkach międzynarodowych (NATO i UE - sic! - obwiniane są o ,masowe łamanie praw człowieka") i militarnej aktywności UE na zewnątrz; sprzeciw wobec udziału niemieckich żołnierzy w misjach UE i NATO; zakończenie współpracy pomiędzy UE a NATO; likwidacja NATO i zastapienie go systemem bezpieczeństwa zbiorowego z udziałem Rosji; likwidację amerykańskich baz wojskowych w państwach UE; w dłuższej perspektywie likwidację armii w Niemczech i Europie. Równie fantastyczne wizje snuje Lewica w odniesieniu do polityki azylowej UE, domagając się m.in. wprowadzenia bezwarunkowego prawa przebywania w UE dla wszystkich uchodźców, zapewnienia im odpowiednich miejsc pobytu, zabezpieczeń socjalnych i wolności wyboru kraju docelowego w Unii, likwidacji obowiązku wizowego w skali Europy (Europa geht..., 2014, s. 55-58). Postulaty w sferze instytucjonalnej obejmują m.in. zdecydowane wzmocnienie Parlamentu Europejskiego i wprowadzenie instytucji referendum europejskiego (Europa geht..., 2014, s. 37). Program dalekiej spadkobierczyni wschodnioniemieckiej Socjalistycznej Partii Jedności Niemiec można potraktować jako mieszankę fantasmagorii i populizmu podszytego wyidealizowanym obrazem Europy i świata.

Eurosceptycznie prezentuje się program Alternatywy dla Niemiec (Alternative für Deutschland) - siły politycznej, która kilka miesięcy przed uformowaniem Parlamentu Europejskiego ósmej kadencji zrobiła furorę na niemieckiej scenie politycznej, niespodziewanie ocierając się o próg wyborczy w jesiennych wyborach do Bundestagu w 2013 r. Zgodnie z jej medialną sławą, opartą w głównej mierze na kontestowaniu wspólnej europejskiej waluty, jej program również w znakomitej większości poświęcony jest krytyce euro oraz europejskiej biurokracji. AfD wylicza negatywne w jej opinii następstwa gospodarcze, jakie przyniosła unia walutowa - łatwo w tym wypadku dostrzec analogię z głosami sceptycznymi wobec unii walutowej, jakie pojawiały się jeszcze przed jej wdrożeniem (Kosman, 2004, s. 30-53) - i może przynieść w przyszłości. Alternatywa opowiada się w związku z tym za stopniowym, zaplanowanym odejściem od euro lub przynajmniej za stworzeniem każdemu państwu warunków do dobrowolnego wystapienia ze strefy euro przy jednoczesnym pozostaniu w UE. AfD skłonna jest 
natomiast zwrócić się ku zasadom zbliżonym do mechanizmów Europejskiego Systemu Walutowego sprzed unii walutowej. Opowiada się także m.in. przeciwko dalszym kredytom w ramach Europejskiego Mechanizmu Stabilizacyjnego, nieograniczonemu skupowaniu długów państwowych przez Europejski Bank Centralny, unii bankowej, za przydzieleniem głosów w EBC proporcjonalnie do wkładu kapitału (co oczywiście faworyzowałoby Niemcy). Eurosceptycyzm AfD przejawia się także w postulacie zweryfikowania istniejącego podziału kompetencji pomiędzy Unią a jej państwami członkowskimi i - gdzie to możliwe - scedowanie kompetencji na powrót na rzecz państw. Służyłoby temu m.in. powołanie specjalnego trybunału odpowiadającego za zasadę subsydiarności (Subsidiarität-Gerichtshof). Oryginalnym pomysłem jest przyznanie prawa weta decyzyjnego dla unijnych płatników netto (bez sprecyzowania, czy chodzi o generalne prawo weta, czy w określonych obszarach integracji) oraz wprowadzenia instytucji weta obywatelskiego. W odniesieniu do spraw instytucjonalnych i budżetowych, Alternatywa domaga się ustalenia jednej siedziby Parlamentu Europejskiego, redukcji Komisji Europejskiej, zmniejszeniu o połowę liczby urzędników UE (ocenianych na 50 tysięcy), redukcji przywilejów podatkowych osób pobierających wynagrodzenie ze środków UE i generalnego obniżenia wydatków budżetowych UE. AfD wyraźnie zatem stara się profilować jako partia stawiająca na politykę oszczędnościową i krytyczną wobec rozbudowanego aparatu urzędniczego UE. Prezentuje także wyraziste poglądy w sprawie rozszerzenia UE. Ich rdzeniem jest przekonanie, iż Europa posiada określone granice geograficzne, historyczne i kulturowe, które nie powinny być naruszane. Jest to równoznaczne z odrzuceniem kandydatury Turcji (postulat zbieżny z chadekami). Jednocześnie Alternatywa przedstawia ofertę statusu stowarzyszeniowego dla bliskich geograficznie państw pozaeuropejskich. W przypadku kolejnych rozszerzeń o państwa europejskie domaga się ścisłego przestrzegania kryteriów akcesyjnych, prawa Niemców do referendów w sprawie kolejnych rozszerzeń oraz utrzymania odpowiedniego poziomu konsolidacji Unii. Partii jest bliska także idea różnych prędkości UE. Stosunkowo niewiele miejsca Alternatywa poświęca zagadnieniom Wspólnej Polityki Zagranicznej i Bezpieczeństwa (Mut..., 2014, s. 3-11). Wyraża poparcie dla WPZB ,w obszarach, w których UE reprezentuje wspólne interesy jej państw członkowskich”, zaś „,w obszarach polityki, które zgodnie z prawem UE leżą w kompetencjach państw członkowskich, Wspólna Polityka Zagraniczna i Bezpieczeństwa musi orientować się na interesy narodowe". WPZB w percepcji Alternatywy jest wypadkową interesów narodowych, w związku z czym w programie położony został akcent na stosunki Niemiec z Francją, USA i Rosją. Z polskiej perspektywy istotne wydaje się być zdanie mówiące o poświęceniu szczególnej uwagi stosunkom ze wschodnimi sąsiadami i współpracy wraz z nimi w rozwiązywaniu kwestii spornych pomiędzy Rosją a innymi państwami poradzieckimi. W programie AfD potwierdzona została zasadnicza rola NATO w utrzymywaniu architektury bezpieczeństwa transatlantyckiego. AfD jest przeciwna tworzeniu armii europejskiej czy urzędu europejskiego ministra obrony. Nie aprobuje również udziału niemieckich żołnierzy w misjach zagranicznych, jeśli nie jest on uzasadniony interesem państwa (Mut.., 2014, s. 11-12). Analiza programu AfD pozwala potwierdzić eurosceptyczny rys tej partii, dążenie do cofnięcia niektórych dotychczasowych rezultatów integracji (zwłaszcza integracji walutowej) i akcentowanie rangi interesów narodowych. 
Poza omówioną grupa partii, które wprowadziły do Parlamentu Europejskiego po kilku posłów, wypada również wymienić parę ugrupowań, które zdobywając po jednym mandacie stały się głównymi beneficjentami zniesienia klauzuli wyborczej. Pierwszą z nich jest przedstawiający się jako ugrupowanie przedstawicieli różnych zawodów, ekspertów, polityków lokalnych czy bezpartyjnych wspólnot wyborczych związek Wolni Wyborcy (Freie Wähler). Jego poglądy w sprawach europejskich można uznać za względnie centrowe, co jest zresztą zgodne z jego autodefinicją („Niezależna siła środka" - Unabhängige Kraft der Mitte). W programie wyborczym z 29 marca 2014 r. opowiadają się więc za okrojeniem liczebnym Komisji Europejskiej i generalnie liczby urzędów w UE oraz za wzmocnieniem Parlamentu Europejskiego, który miałby współdecydować m.in. o sprawach wspólnej waluty. Wolni Wyborcy jednocześnie dalecy są od projektów o charakterze federalistycznym - świadczą o tym postulaty wzmocnienia struktur lokalnych i regionalnych w państwach Unii oraz ugruntowania pozycji Komitetu Regionów jako przedstawicielstwa wspólnot subnarodowych. Wolni Wyborcy pragną też wzmocnienia statusu języka niemieckiego w UE (Europa bist $d u$.., 2014, s. 15-17). Blisko im zatem w tych postulatach do bawarskiej CSU. Niewiele miejsca w programie poświęcają natomiast problematyce relacji zewnętrznych UE, przeważnie nie wychodząc poza tradycyjne formuły umiarkowanych ugrupowań. Opowiadają się zatem za bliską współpracą UE z innymi organizacjami międzynarodowymi, wzmocnieniem Europejskiej Służby Działań Zewnętrznych, koordynacją wspólnej przestrzeni bezpieczeństwa razem z NATO. Odważnym postulatem jest natomiast wprowadzenie głosowań większościowych i wciągnięcie Parlamentu Europejskiego do procesów decyzyjnych w zakresie Wspólnej Polityki Bezpieczeństwa i Obrony. Zalecają natomiast ostrożność w debacie dotyczącej dalszego rozszerzania Unii Europejskiej i choć deklarują się generalnie jako otwarci na inne kraje kandydujące, to na chwilę obecną są przeciwni rozszerzeniu o którekolwiek państwo (Europa bist du..., 2014, s. 56-59).

Następnym ugrupowaniem, które uzyskało mandat w Parlamencie Europejskim, jest Partia Piratów (Piratenpartei Deutschland). Formacja, której kilka lat wcześniej wróżono wejście do Bundestagu, wyraźnie straciła na popularności, jednak nie na tyle, żeby całkowicie zniknąć z niemieckiej sceny politycznej. Centralne punkty jej programu wyborczego stanowią w zasadzie powtórzenie dotychczasowych postulatów związanych z wolnością w przestrzeni wirtualnej (wolnym dostępem do Internetu), prawem do anonimowości w Internecie, poprawą standardów ochrony danych osobowych, ograniczeniem praw autorskich i patentowych, nałożeniem ograniczeń na zjawisko lobbingu w Europie. Wiele miejsca partia poświęca problemom ochrony konsumentów, ochrony zdrowia i środowiska naturalnego. Piraci opowiadają się za otwartą polityką azylową. Problematyka zewnętrznych relacji UE przewija się w mniejszym stopniu, objawia się w dość krzykliwym odrzuceniu planowanej umowy o wolnym handlu pomiędzy UE a USA (autorzy dokumentu postrzegają ją głównie jako narzędzie wprowadzania żywności modyfikowanej genetycznie na rynek europejski oraz niepożądanego wzmocnienia praw autorskich i pogorszenia poziomu ochrony danych osobowych). Z kolei zagadnienia Wspólnej Polityki Bezpieczeństwa i Obrony są potraktowane bardzo oględnie - Piraci żądają bardziej transparentnej, poddanej demokratycznej kontroli WPBO, zgody Bundestagu na każdorazowe użycie wojsk Bundes- 
wehry poza granicami państwa czy zaprzestania przez państwa Unii eksportu broni poza jej obszar. Autorzy programu oceniają że państwom UE nie grożą żadne poważne niebezpieczeństwa. Można odnieść wrażenie, że Wspólna Polityka Zagraniczna i Bezpieczeństwa oraz Wspólna Polityka Bezpieczeństwa i Obrony nie są mocną stroną Piratów - co nie dziwi, bowiem główny punkt ciężkości ich programu ulokowany jest na swobodnym dostępie do przestrzeni wirtualnej. Jeśli chodzi natomiast o kwestie instytucjonalne, nie wychodzą oni poza często przywoływany przez niektóre inne partie postulat inicjatywy legislacyjnej dla Parlamentu Europejskiego czy wprowadzenia ułatwień dla stosowania mechanizmu inicjatywy ludowej (przewidzianego Traktatem z Lizbony). Pewną ciekawostką jest postulat odrzucenia zmiany czasu z zimowego na letni bądź odwrotnie, nieco satyrycznym zaś jego elementem jest zamysł przeprowadzenia referendum w sprawie wyboru obowiązującego czasu (EU-Wahlprogramm Piraten, 2014).

Kolejną partia, która uzyskała mandat w Parlamencie Europejskim, jest niezbyt znana szerzej Partia Ochrony Zwierząt (Tierschutzpartei). Nie budzi zaskoczenia fakt, że właśnie poprawę losu zwierząt uczyniła przodującym celem swojego programu wyborczego. W ten kontekst wpisują się także postulaty związane z polityką rolną, rybołówstwem, ochroną środowiska czy ochroną konsumentów. Partia krytycznie odnosi się do aspektów polityki Stanów Zjednoczonych związanych z tzw. aferą podsłuchową. W części programu poświęconej polityce bezpieczeństwa i obrony UE, koncentruje się na krytyce nadmiernych - jej zdaniem - wydatków na sferę wojskową, które mogłyby zostać wykorzystane na inne cele. Odnośnie konfliktów zbrojnych, domaga się prymatu polityki prewencji nad zaangażowaniem wojskowym, przekazania Parlamentowi Europejskiemu kompetencji kontrolno-decyzyjnych w sferze WPBO, ograniczania zbrojeń przez państwa UE (zmniejszanie budżetów obronnych, redukcja przemysłu zbrojeniowego), wywierania przez UE nacisków na redukcję broni jądrowej na świecie (Europawahlprogramm. „Europa neu gestalten..., 2014, s. 2-11). Program w odniesieniu do WPBO ogranicza się w zasadzie do zbioru pacyfistycznych postulatów, przypominając raczej myślenie życzeniowe niż realny obraz stosunków międzynarodowych.

Niewiele uwagi problemom polityki bezpieczeństwa i obrony na szczeblu UE poświęca Partia Rodzin (Familien-Partei Deutschlands). Ogranicza się do zaleceń, aby naczelnym celem polityki wojskowej każdego z państw członkowskich UE było utrzymanie pokoju, zaś wszelkie wojskowe zaangażowanie poza Europą powinno być ostatecznością i rozpatrywane z zachowaniem najwyższej rozwagi. Partia akcentuje konieczność otoczenia szczególną ochroną dzieci podczas konfliktów zbrojnych, opowiada się także za ograniczeniem eksportu broni (Familien-Partei..., 2014, s. 12). Zgodnie z profilem ugrupowania, najwięcej miejsca w programie wyborczym poświęcono postulatom ochrony rodziny, takim jak uznanie wychowania dzieci za równorzędne pracy zawodowej (przyznanie wynagrodzenia za wychowywanie), dotacje na dzieci, stworzenie urzędów doradztwa wspierających wysiłek wychowawczy rodziców czy udogodnienia finansowe dla pracodawców sprzyjających rodzicom (Familien-Partei..., 2014, s. 4-5).

Skromnie pod względem rozmiarów prezentuje się z kolei ujęty w szesnaście krótkich rozdziałów, pięciostronicowy program Partii Ekologiczno-Demokratycznej 
(Ökologisch-Demokratische Partei). Podkreślono w nim chrześcijańsko-humanistyczne korzenie Europy, która powinna utrzymać swój charakter związku państw (podobnie uważa Partia Rodzin). Główne postulaty odnośnie zmian instytucjonalnych odnosiły się - jak w przypadku wielu innych ugrupowań - do wzmocnienia Parlamentu Europejskiego (samodzielność legislacyjna, prawo do określania przychodów i wydatków Unii, możliwość proponowania kandydatów na komisarzy KE i ich dymisjonowania, podporządkowanie KE Parlamentowi Europejskiemu), jednolitej ordynacji w wyborach do PE, utworzenia drugiej izby parlamentarnej. Partia Ekologiczno-Demokratyczna opowiada się za utrzymaniem i trwałością wspólnej waluty, jednak krytycznie ocenia dotychczasowe mechanizmy ratunkowe w dobie kryzysu. Spora część programu poświęcona jest ochronie środowiska naturalnego, rolnictwu, prawom konsumentów i prawom zwierząt. Z kolei rozdział omawiający Wspólną Politykę Zagraniczną i Bezpieczeństwa obfituje w krytykę dotychczasowych osiagnięć w tej sferze, a nawet zarzutów, iż Traktat o Unii Europejskiej dopuszcza wojny agresywne ze strony UE. Autorzy dokumentu domagają się zmiany traktatu, ,aby zakazane zostały wojny UE o ropę, surowce i zabezpieczenie szlaków handlowych" (Kurzprogramm der ÖDP ..., 2014, s. 7-8). Te absurdalne opinie wpisują się w percepcję kilku innych, niewielkich (z wyjątkiem Die Linke) skrajnie lewicowych ugrupowań, cieszących się nikłym, oscylującym wokół jednego procenta poparciem.

Na przeciwnym biegunie niemieckiej sceny politycznej lokuje się Narodowodemokratyczna Partia Niemiec (Nationaldemokratische Partei Deutschlands), ciesząca się wątpliwą sławą ugrupowania neonazistowskiego, poddana w ostatnich latach nieudanym próbom delegalizacji. Jej program wyborczy przed elekcją do PE, umieszczony na stronach internetowych partii, jest dokumentem, w którym tytuł preambuły sugeruje wyraźną kontestację Unii: „Tak dla Europy, nie dla takiej UE - gdyż Europa powinna także w przyszłości pozostać przestrzenią życiową Europejczyków!" (Ja zu Europa, Nein zu dieser EU - weil Europa auch in Zukunft Lebensraum der Europäer bleiben soll!). NPD zapewnia o poszanowaniu dla wielokulturowości kontynentu, odwołuje się do historii i spuścizny kulturowej Europy (pojawiają się odniesienia do walki z najazdami islamskimi na kontynent od Karola Młota po Jana III Sobieskiego). NPD jednoznacznie ocenia, iż powyższe wartości są obecnie zagrożone m.in. przez UE, która dysponuje nadmiernym prawem ingerencji w wiele dziedzin aktywności społecznej, takich jak np. oświata czy ochrona zdrowia. Szczególnie krytycznie wypowiada się także na temat imigracji do UE, sama Unia oceniana jest jako „oddalony od obywateli, coraz bardziej totalitarny moloch" (Europa wählt..., 2014, s. 9-10). NPD podważa cały szereg dotychczasowych osiagnięć integracji, jak wspólne reguły dotyczące polityki gospodarczej czy socjalnej, uważając że kompetencje w tych sferach powinny leżeć w gestii państw. Unia - zdaniem NPD - ewoluuje w kierunku „totalitarnego państwa represyjnego na wzór ZSRR". Pojawiają się postulaty przywrócenia kontroli na granicach wewnętrznych UE, powstrzymania imigracji do UE (także wyspecjalizowanej siły roboczej), przeniesienia polityki imigracyjnej i azylowej z powrotem na szczebel narodowy (Europa wählt..., 2014, s. 20-21). Odrzucone zostają antykryzysowe mechanizmy stabilizacyjne na szczeblu Unii, co więcej - partia domaga się rozwiązania unii walutowej i możliwości powrotu do walut narodowych. Z kolei odnośnie polityki zagranicznej i bezpieczeństwa UE, lektura programu pozwala dostrzec silne akcenty an- 
tyamerykańskie. Partia krytykuje zaangażowanie UE w sprawy Europy Wschodniej, Bliskiego Wschodu, plany instalacji komponentów amerykańskiej tarczy antyrakietowej w Europie Środkowej i Południowej i ogólnie współpracę w sferze bezpieczeństwa ze Stanami Zjednoczonymi (określając ją wręcz jako politykę wasalną wobec USA). NPD domaga się zatem: uniezależnienia w tej sferze od USA, rozbudowy stosunków z Rosją (akcentując zwłaszcza potrzebę bilateralnej współpracy niemiecko-rosyjskiej); nieingerencji Unii w sprawy „sąsiednich dużych przestrzeni (Grossräume)" - nietrudno się domyślić, że chodzi o poszanowanie strefy wpływów Rosji; wzmocnienia - także wojskowych - środków ochrony Unii przed nadmierną imigracją; przerwania negocjacji akcesyjnych z Turcją; rozwiązania wielonarodowych formacji zbrojnych w UE; wycofania z Europy „,wszystkich obcych, zwłaszcza amerykańskich oddziałów” i komponentów planowanej tarczy antyrakietowej; weryfikacji współpracy wywiadowczej z krajami pozaeuropejskimi; reanimacji europejskiego przemysłu zbrojeniowego; wreszcie utworzenia bliżej nieokreślonego Europejskiego Paktu Obronnego (Europäischer Verteidigungspakt) jako formy koordynacji polityki bezpieczeństwa Unii (Europa wählt..., 2014, s. 27-33). Dokument NPD jest w zasadzie kontestacją dotychczasowych osiagnięć integracji europejskiej, skupiającą się na nośnych radykalnych hasłach i postulatach, wśród których na czoło wysuwają się treści antyimigranckie, antyamerykańskie czy dążenie do umacniania państw narodowych jako fundamentu konstrukcji politycznej Europy. Można założyć, że realizacja takiego programu stanowiłaby radykalny odwrót od integracji europejskiej oraz współpracy transatlatnyckiej i odradzanie się na kontynencie koncertu mocarstw, także z udziałem Rosji.

Ostatnie z omawianych ugrupowań, któremu powiodły się starania wejścia do PE, nosi nazwę PARTEI - skrót ten rozszyfrowywany jest jako Partei für Arbeit, Rechtsstaat, Tierschutz, Elitenförderung und basisdemokratische Initiative. Jest to ugrupowanie o wyraźnie satyrycznym profilu, o czym świadczą fragmenty mieszczącego się na jednej stronie dokumentu, określanego jako program wyborczy. Próbką poczucia humoru autorów mogą być np. takie postulaty, jak: zagwarantowanie 17-procentowej kwoty „wiodących stanowisk w europejskiej gospodarce dla wykwalifikowanych leni, miglanców (Drückeberger) i nierobów (Müßiggänger)"; budowa muru wokół Szwajcarii; ustalenie maksimum egzystencji na kwotę $1 \mathrm{mln}$ (bez wskazania waluty, z preferencją dla dawnej marki wschodnioniemieckiej); przeprowadzenie procesu pokazowego Angeli Merkel umieszczonej w klatce na Stadionie Olimpijskim w Berlinie; zakaz nakłaniania kogokolwiek do podjęcia pracy przed trzydziestym rokiem życia, czy wreszcie wprowadzenie czynnego prawa wyborczego dla osób w wieku 12-52 lat (PARTEI-Programm..., 2014). To ostatnie zresztą nie zaskakuje (abstrahując oczywiście od satyrycznego wymiaru tej propozycji), bowiem klientela wyborcza PARTEI rekrutuje się przeważnie spośród najmłodszych obywateli.

\section{Uwagi końcowe}

Obywatele Niemiec poszli do urn wyborczych 25 maja 2014 r., by wyłonić 96 deputowanych na ogólną - ustaloną Traktatem z Lizbony - liczbę 751 członków Parlamentu Europejskiego. Zgodnie z przewidywaniami, partie wielkiej koalicji zajęły czołowe 
miejsca - chadecy uzyskali łącznie ponad 35\% głosów, socjaldemokraci zajęli drugą pozycję z $27 \%$ poparcia. Kolejne lokaty przypadły Zielonym, Lewicy, AfD i FDP. Siedem małych ugrupowań otrzymało poparcie pomiędzy $0,6-1,5 \%$. Pozwoliło to im na objęcie po jednym mandacie w PE. Każda z pozostałych jedenastu partii uzyskała rezultat poniżej $0,5 \%$ - zbyt mało, aby uczestniczyć w podziale mandatów. Biorąc pod uwagę kraje związkowe, w czterech zwyciężyła SPD (Brandenburgia, Berlin, Hamburg, Brema), w jedenastu CDU i w Bawarii oczywiście CSU. Analiza wyników pozwala dostrzec kilka zjawisk:

- partie, które dostały się do Bundestagu w wyborach z grudnia 2013 r., weszły również do Parlamentu Europejskiego - w tym kontekście można mówić o względnej stabilności zachowań wyborczych;

- w ścisłej czołówce znalazły się partie zasadniczo aprobujące dotychczasowe osiagnięcia i aktualny kształt integracji europejskiej, postulujące jedynie - większe lub mniejsze - korekty w poszczególnych dziedzinach (chadecy, socjaldemokraci, Zieloni). W szerokiej czołówce znalazły się natomiast ugrupowania wyrażające spore zastrzeżenia do dotychczasowych rezultatów procesów integracyjnych (Lewica, AfD);

- beneficjentem likwidacji klauzuli zaporowej stała się FDP, która kilka miesięcy wcześniej nie dostała się do Bundestagu. Poparcie dla liberałów w obu wyborach utrzymało się na zbliżonym poziomie. Gdyby jednak wybory do PE odbywały się w podobnej formule, jak w 2009 roku (tj. z uwzględnieniem progu 5\%), nie zdołaliby uzyskać żadnego mandatu (przekroczyliby natomiast próg 3\%, gdyby taki pozostał, zgodnie ze wspomnianą wcześniej ustawą z 2013 r.);

- duży sukces odnotowała AfD, poprawiając o ponad $2 \%$ swój wynik z wyborów do Bundestagu, w których otarła się o próg wyborczy. Jest to świadectwo rosnącej popularności Alternatywy, przed którą otwiera się szansa zdyskontowania swojej obecności w PE na krajowej scenie politycznej. Z drugiej strony pewnego rodzaju „monotematyczność” jej programu (tj. głównie krytyka wspólnej waluty) może z czasem prowadzić do spadku popularności (tak jak w przypadku Partii Piratów), zwłaszcza w przypadku poprawy sytuacji gospodarczej w strefie euro;

- Zniesienie progu wyborczego, które nastapiło oczywiście na korzyść drobnicy partyjnej, odbyło się kosztem niemal wszystkich ugrupowań, cieszących się dotąd stosunkowo stabilną obecnością na niemieckiej scenie politycznej (CDU, CSU, Zieloni, FDP, Lewica). Zanotowały one spadek liczby mandatów w porównaniu z wyborami z 2009 r. Jedynie SPD poprawiła swój wynik o cztery mandaty.

\section{Załącznik 1}

\section{Ugrupowania biorące w Niemczech udzial w wyborach do Parlamentu Europejskiego w 2014 roku (źródło: www.bundeswahlleiter.de)}

1. Christlich Demokratische Union Deutschlands (CDU)

2. Sozialdemokratische Partei Deutschlands (SPD)

3. Bündnis 90/Die Grünen (GRÜNE)

4. Freie Demokratische Partei (FDP) 
5. Die Linke (DIE LINKE)

6. Christlich-Soziale Union in Bayern (CSU)

7. Freie Wähler (FREIE WÄHLER)

8. Die Republikaner (REP)

9. Partei Mensch Umwelt Tierschutz (Tierschutzpartei)

10. Familien-Partei Deutschlands (FAMILIE)

11. Piratenpartei Deutschland (PIRATEN)

12. Ökologisch-Demokratische Partei (ÖDP)

13. Partei Bibeltreuer Christen (PBC)

14. Ab jetzt...Demokratie durch Volksabstimmung - Politik für die Menschen (Volksabstimmung)

15. Bayernpartei (BP)

16. Christliche Mitte - Für ein Deutschland nach Gottes Geboten (CM)

17. AUF - Partei für Arbeit, Umwelt und Familie, Christen für Deutschland (AUF)

18. Deutsche Kommunistische Partei (DKP)

19. Bürgerrechtsbewegung Solidarität (BüSo)

20. Partei für Soziale Gleichheit, Sektion der Vierten Internationale (PSG)

21. Alternative für Deutschland (AfD)

22. Bürgerbewegung PRO NRW (PRO NRW)

23. Marxistisch-Leninistische Partei Deutschlands (MLPD)

24. Nationaldemokratische Partei Deutschlands (NPD)

25. Partei für Arbeit, Rechtsstaat, Tierschutz, Elitenförderung und basisdemokratische Initiative (Die PARTEI)

Zalącznik 2

Wyniki wyborów do Parlamentu Europejskiego 2014 roku w Niemczech

(źródło: opracowanie własne na podstawie www.bundeswahlleiter.de)

\begin{tabular}{|l|c|c|c||}
\hline \multicolumn{1}{|c|}{ Wyszczególnienie } & Glosy wyborców & Wynik procentowy & $\begin{array}{c}\text { Liczba } \\
\text { deputowanych }\end{array}$ \\
\hline \multicolumn{1}{|c|}{1} & 2 & 3 & 4 \\
\hline Liczba uprawnionych & 61998824 & - & - \\
\hline Liczba oddanych głosów & 29843798 & 48,1 & - \\
\hline Głosy nieważne & 488706 & 1,6 & - \\
\hline Głosy ważne & 29355090 & 98,4 & 29 \\
\hline CDU & 8812653 & 30,0 & 11 \\
\hline SPD & 8003628 & 27,3 & 7 \\
\hline GRÜNE & 3139274 & 10,7 & 7 \\
\hline DIE LINKE & 2168455 & 7,4 & 5 \\
\hline AfD & 2070014 & 7,1 & 3 \\
\hline CSU & 1567448 & 5,3 & 1 \\
\hline FDP & 986841 & 3,4 & 1,5 \\
\hline FREIE WÄHLER & 428800 & & \\
\hline
\end{tabular}




\begin{tabular}{|c|c|c|c|}
\hline 1 & 2 & 3 & 4 \\
\hline PIRATEN & 425044 & 1,4 & 1 \\
\hline Tierschutzpartei & 366598 & 1,2 & 1 \\
\hline NPD & 301139 & 1,0 & 1 \\
\hline FAMILIE & 202803 & 0,7 & 1 \\
\hline ÖDP & 185244 & 0,6 & 1 \\
\hline Die PARTEI & 184709 & 0,6 & 1 \\
\hline REP & 109757 & 0,4 & - \\
\hline Volksabstimmung & 88535 & 0,3 & - \\
\hline BP & 62438 & 0,2 & - \\
\hline $\mathrm{PBC}$ & 55336 & 0,2 & - \\
\hline PRO NRW & 52649 & 0,2 & - \\
\hline AUF & 50953 & 0,2 & - \\
\hline $\mathrm{CM}$ & 30136 & 0,1 & - \\
\hline DKP & 25147 & 0,1 & - \\
\hline MLPD & 18198 & 0,1 & - \\
\hline BüSo & 10369 & 0,0 & - \\
\hline PSG & 8924 & 0,0 & - \\
\hline
\end{tabular}

\section{Bibliografia}

Europa bist du. Misch dich ein. Europawahlprogramm der Freien Wähler zur Wahl des Europäischen Parlaments am 25. Mai 2014 (2014), www.freiewaehler.eu.

Europa eine neue Richtung geben. Wahlprogramm für die Europawahl am 25. Mai 2014 (2014), www.spd.de.

Europa geht anders: sozial, friedlich, demokratisch (2014), 25. Mai 2014, www.die-linke.

Europa mitentscheiden, erneuern, zusammenhalten. Europawahlprogramm 2014 von Bündnis 90/Die Grünen (2014), www.gruene.de.

Europa wählt rechts. Das Europaprogramm der NPD. Verabschiedet vom NPD-Parteipräsidium am 10. Januar 2014 in Dresden (2014), npd.de.

Europaplan Bayern. Das Programm der CSU zur Europawahl 2014. Beschluss des Kleinen Parteitags vom 10. Mai 2014 (2014), www.csu.de.

Europawahlprogramm. „Europa neu gestalten - mehr Demokratie und mehr Europa wagen!” (2014), www.tierschutzpartei.de.

EU-Wahlprogramm Piraten (2014), program wyborczy Partii Piratów uchwalony na zjeździe w Bochum 4-5 stycznia 2014 r., www.piratenpartei.de.

Familien-Partei Deutschlands. Wahlprogramm für die Wahl zum 8. Europäischen Parlament 2014 (2014), www.familien-partei-deutschlands.de.

Fünftes Gesetz zur Änderung des Europawahlgesetzes vom 7. Oktober 2013 (2013), Bundesgesetzblatt I, 9.10.2013.

Gemeinsam erfolgreich in Europa (2014), 5. April 2014, Berlin, www.cdu.de.

Gesetz über die Wahl der Abgeordneten des Europäischen Parlaments aus der Bundesrepublik Deutschland (Europawahlgesetz - EuWG) (1994), Bundesgesetzblatt I, 12.03.1994.

Kietz D., von Ondarza N. (2014), Europaskeptiker im Europäischen Parlament, SWP-Aktuell 7, Februar. 
Kosman M. M. (2009), Parlament Europejski-wybrane aspekty ewolucji, „Świat Idei i Polityki”, t. 9. Kosman M. M. (2004), Zjednoczone Niemcy w procesie integracji europejskiej (1990-2002), Toruń. Kurzprogramm der ÖDP zur Europawahl 2014 (2014), www.oedp-bayern.de.

Mudde C. (2014), Rechtsaußen, die Große Rezession und die Europa-Wahlen 2014, „Aus Politik und Zeitgeschichte", $\mathrm{nr} 12$.

Mut zu Deutschland. Für ein Europa der Vielfalt. Programm der Alternative für Deutschland für die Wahl zum Europäischen Parlament am 25. Mai 2014 (2014), Beschluss des Bundesparteitags vom 22. März 2014, www.alternativefuer.de.

Leitsätze zum Urteil des Zweiten Senats vom 26. Februar 2014 (2014), orzeczenie Federalnego Trybunału Konstytucyjnego z 26 lutego 2014 r., www.bundesverfassungsgericht.de.

Leitsätze zum Urteil des Zweiten Senats vom 9. November 2011 (2011), orzeczenie Federalnego Trybunału Konstytucyjnego z 9 listopada 2011 r., www.bundesverfassungsgericht.de.

PARTEI-Programm zur EU-Wahl 2014 (2014), www.die-partei.de.

Peters M. (2014), Demokratie durch Kritik: Wider die EU-Skepsis, „Aus Politik und Zeitgeschichte”, nr 12.

Programm der Freien Demokratischen Partei für die Wahl zum VIII. Europäischen Parlament 2014. Das braucht unser Europa! (2014), Beschluss des Europaparteitages der FDP, Bonn, 19. Januar 2014, www.fdp.de.

Węc J. J. (2011), Traktat lizboński. Polityczne aspekty reformy ustrojowej Unii Europejskiej w latach 2007-2009, Kraków.

\section{Streszczenie}

Parlament Europejski przeszedł w ciągu ponad sześciu dekad swego istnienia znaczącą ewolucję, zarówno w wymiarze ilościowym, jak i jakościowym. Od 1979 r. wyłaniany jest w oparciu o powszechne wybory. Ostatnie wybory odbyły się w maju 2014 r. W Niemczech wybierano 96 posłów. Nieco wcześniej Federalny Trybunał Konstytucyjny zlikwidował klauzulę wyborczą, dzięki czemu aż 14 partii niemieckich dostało się do Parlamentu Europejskiego. Najwięcej głosów zdobyły tradycyjne partie - chadecy i socjaldemokraci. Aż siedem partii uzyskało po jednym mandacie. Głównym celem artykułu jest analiza programów wyborczych partii niemieckich biorących udział w rywalizacji wyborczej, zwłaszcza kwestie Wspólnej Polityki Zagranicznej i Bezpieczeństwa oraz problemów instytucjonalnych UE. Autor dokonuje ponadto analizy wyników wyborów i prezentuje wnioski dotyczące ewolucji niemieckiej sceny politycznej.

Słowa kluczowe: Parlament Europejski, wybory, programy wyborcze, CDU, CSU, SPD, Lewica, FDP, AfD, Unia Europejska, ordynacja wyborcza, klauzula wyborcza, reformy instytucjonalne UE, Wspólna Polityka Zagraniczna i Bezpieczeństwa UE

\section{Platforms of German political parties in the 2014 election to the European Parliament. Selected aspects}

\section{Summary}

In the period of over six decades of its operations, the European Parliament has evolved considerably, both in quantitative and qualitative terms. Since 1979, the EP has been elected in gene- 
ral elections. The latest were held in May 2014. Ninety-six members of the EP were elected in Germany. Before the elections, the Federal Constitutional Court in Germany abandoned the threshold clause, allowing as many as fourteen German political parties to enter the EP. The traditional parties, the Christian Democrats and Social Democrats, won the majority of votes. As many as seven parties won a single mandate. The main purpose of this paper is to analyse the election platforms of German parties competing in the elections, in particular as concerns the matters of the Common Foreign and Security Policy and institutional problems faced by the EU. The analysis of the election results is also made, followed by conclusions on the evolution of German political arena.

Key words: European Parliament, election, election platforms, CDU, CSU, SPD, Left-wing, FDP, AfD, European Union, electoral law, electoral clause, EU institutional reform, Common Foreign and Security Policy of the EU 